\title{
Is Zero Disarmament Possible? Multilateralism and Nuclear Arms Control Treaties
}

\section{P. Sean Morris*}

This article concerns two Cold War treaties on nuclear nonproliferation and arms control and whether the success of one treaty can be instrumental in leading to the reduction of nuclear weapons. The Nuclear Non-Proliferation Treaty (NPT) and the Intermediate-Range Nuclear Forces Treaty (INF) have been essential to world peace. Although it might be impossible to envisage a world free of nuclear weapons, the post-Cold War nuclear posture requires multilateral engagement to prevent the further spread of nuclear weapons technology and treaties such as the $N P T$ can be amended to include the INF treaty and therefore lead to further nuclear disarmament. This is because the NPT treaty has been granted indefinite extension and the INF treaty has been one of the success stories in nuclear disarmament and that success should be further built upon. The paper is not an exhaustive discussion of the nuclear treaties regime-rather the arguments and policy prescription in the paper are illustrative.

\section{INTRODUCTION}

Nuclear arms control and disarmament ${ }^{1}$ have been the subject of a number of treaties ${ }^{2}$ both at the multilateral and regional level ever since the destructive nature of nuclear weapons was

\footnotetext{
* Faculty of Law, University of Helsinki. I am grateful to Jan Klabbers, Anne van Aaken, Jutta Brunee and an anonymous reviewer of this journal for comments on various drafts of this paper. Furthermore, the staff of this journal has been diligent with their cite-checking and editing, and for this I am also thankful. The views are that of the author alone. This essay is a slightly revised version of a 2014 paper.

${ }^{1}$ In this article, treaties regarding nuclear weapons such as The Treaty Between the United States of America and the Union of Soviet Socialist Republics on the Elimination of their Intermediate-Range and Shorter-Range Missiles, (hereinafter "INF Treaty") and the Treaty on the Non-Proliferation of Nuclear Weapons (hereinafter "NPT Treaty") are collectively referred to as "nuclear arms control treaties."

${ }^{2}$ U.S. Library of Congress, Congressional Research Service, Arms Control and Non-proliferation: A Catalog of Treaties and Agreements, by Amy Woolf, Paul Kerr, and Mary Nikitin, RL33865 (2016); Nenne Bodell, "Annex A. Arms Control and Disarmament Agreements," in SIPRI Yearbook 2010: Armaments, Disarmament and International Security (New York: Oxford University Press, 2010), 478, 494; Lisa Schenck and Robert Youmans, "From Start to Finish: A Historical Review of Nuclear Arms Control Treaties and Starting Over with the New START," Cardozo Journal of International and Comparative Law 20, no. 399 (2012): 399-436.
} 
uncovered in the Hiroshima bombings of August 6, 1945. Most of the nuclear arms control treaties in the aftermath of the Second World War dealt with different aspects of nuclear technology, such as banning, testing, nuclear free zones, proliferation and disarmament. These treaties formed the main legal structure that governed Cold War relations and later disarmament. ${ }^{3}$

At the multilateral level, nuclear arms control agreements generally involve a pledge not to spread nuclear weapons technology - the nonproliferation consensus-while at the regional level, the pledge generally involves limits on the number of nuclear warheads and the technology for manufacturing such weapons. The two most important treaties at the multilateral and regional levels are the 1968 nuclear Non-Proliferation Treaty (NPT) and the Intermediate-Range Nuclear Forces Treaty (INF). These treaties generally involve nuclear armed states, or are bilateral in nature, that is, between the two Cold War superpowers, the United States and the Soviet Union. The INF Treaty was initially a bilateral treaty. However, due to the disintegration of the Soviet Union in 1991, the INF Treaty is now regarded as a multilateral treaty given that the USSR successor states replace the USSR in the INF Treaty.

Within the international legal system, the relationship between the nuclear arms control treaties is generally seen as vertical and horizontal proliferation. In other words, states with nuclear weapons represent vertical proliferation, that is, an increase in their stockpile, whilst horizontal proliferation refers to the spread of nuclear weapons to non-nuclear powers or those states' abilities to make them. ${ }^{4}$ The NPT represents efforts at preventing horizontal proliferation as well as indirectly referring to the prohibition of vertical proliferation when its legal provisions, such as Article VI, are taken into account.

In the case of the INF, I would argue that there is a third rung outside of horizontal and vertical proliferation - circuit proliferation - that is, arms control treaties pertaining to nuclear weapons create a certain distrust among treaty members. Such distrust is also exacerbated by the fact that

3 U.S. Delegation. "Treaty on the Non-Proliferation of Nuclear Weapons." Paper presented at the Nuclear Nonproliferation Treaty Review Conference, New York, 2010.

${ }^{4}$ Jita Mishra, The NPT and the Developing Countries (New Delhi: Concept Publishing, 2008), 3. The author also notes that, "[v]ertical and horizontal proliferation are linked by the fact that the most non-nuclear weapon powers would like to see a reduction in vertical proliferation, while nuclear powers have focused on reducing horizontal proliferation." Matthew Lund, "The Eighty Percent and Twenty Percent Solutions to Nuclear Proliferation," BYU Law Review 741, no. 3 (2009): 1-42; Theodore B. Taylor, "Nuclear Disarmament and Peaceful Technology-Can We Have Both?" in New Technologies and the Arms Race, ed. Carlo Schaerf et al. (London: MacMillan Press, 1989), 200. The authors explain that, "[h]orizontal proliferation refers to the acquisition of nuclear weapons by more countries. Vertical proliferation refers to increases in the numbers and diversity of nuclear weapons of a nation after it has initially acquired (nuclear weapons)."; Vitaly Goldansky, "Connection between Horizontal and Vertical Proliferation of Nuclear Weapons," in Coexistence, Cooperation and Common Security: Annals of the Pugwash Conference, eds. Joseph Rotbat and Laszlo Valki (London: MacMillan, 1988), 21. 
new technologies make treaties such as the INF obsolete for modern threats. The circuit proliferation relationship is however, a moot argument for another place and time. ${ }^{5}$

The NPT and INF have been at the center stage of horizontal and vertical proliferation for decades. Both treaties represent certain geographic "centers of power" such as Europe and Russia or Russia and the US. Although these treaties have different goals, their futures are somewhat intertwined. The INF has relatively been successful in Europe in terms of containment of the spread of short range weapons capable of carrying nuclear warheads. The NPT however, being a multilateral treaty, is still short of the success as the INF Treaty. One major development that can work in favor of the NPT is that it has been extended indefinitely and the extension opens up the possibility for zero disarmament.

According to Article VI of the NPT states are obliged to "pursue negotiations in good faith on effective measures relating to cessation of the nuclear arms race at an early date and to nuclear disarmament." These conditions have not yet been fully met. Nowadays, states are more inclined in acquiring nuclear weapons or modernizing their weapons capable of delivering a nuclear warhead. As a result of such developments, questions regarding the legal state of the global nonproliferation regime will require additional commitments from states regarding compliance to the NPT.

In the post-Cold War era, there is a certain degree of disappointment in the international nuclear arms control regime ${ }^{7}$ because of the existence of the number of nuclear warheads that are still deployed or in storage. Furthermore, the ferocious appetite by states to acquire nuclear weapons technology has thrown into doubt whether full compliance with the NPT can be achieved.

Furthermore, distrust between Russia and NATO members further exacerbates the disappointment given the continued existence of relics of the Cold War in the form of non-strategic nuclear weapons (tactical) that are still based in Europe, and aimed at Russia. ${ }^{8}$ In full reciprocity, Russia also has a nuclear security blanket covering almost all of Europe. However, there is a significant reduction in the amount of nuclear warheads that the five legally recognized nuclear

\footnotetext{
${ }^{5}$ But see e.g., Gabriella Venturini, "Control and Verification of Multilateral Treaties on Disarmament and NonProliferation of Weapons of Mass Destruction," UC Davis Journal of International Law and Policy 17, no. 2 (2011): 346.

${ }^{6}$ Treaty on the Non-Proliferation of Nuclear Weapons, Article VI, Mar. 5, 1970, 1657 U.N.T.S. 161.

7 "Legality of the Threat or Use of Nuclear Weapons," Advisory Opinion, I.C.J. Reports 1996, 226.

${ }^{8}$ Andrei Zagorski, “Tactical Nuclear Weapons," Security \& Human Rights 22, no. 4 (2011): 399-409.
} 
states currently hold, from a high of 39,160 in 1970 to a low of 16,075 in $2014 .{ }^{9}$ Thus, the world is still far from a possibility of complete disarmament.

Since the end of the Cold War, Russia has voiced on many occasions the need for NATO to dismantle, and continues to argue that NATO is no longer relevant in a post-Cold War world. However, such concerns from Moscow are largely ignored. This is all too evident with the expansion of NATO. To the dismay of Moscow, NATO went on a strategic expansion to include not only former Soviet satellite states such as Poland, but to also include states that were once part of the Soviet Union such as Estonia. NATO's expansion has also targeted other former Soviet states that are still in modern Russia's sphere of influence, or "near-abroad" in the language of Russian geopolitics.

These near-abroad states for the purposes of this paper are primarily the Ukraine and Georgia but include a number of others. The rapid expansion of NATO also allowed Russia to rejuvenate its strategic defense policy and increase its defense budget and modernize its armed forces. Thus, the very existence of NATO and its post-Cold War expansion give impetus to Russia to divert from post-Cold War economic and civil society building to strategically rearm for an increasingly brash NATO. ${ }^{10}$ Today, Russia is no longer a weak state that the West has perceived it to be, such as in the late 1990s and early 2000s, as she continues to increase her military spending. ${ }^{11}$

When Russia annexed Crimea in the spring of 2014, NATO members argued that they were vindicated in the alliance's expansion in order to ward off any possible aggression from a belligerent bear to the East. As the Russian-Ukrainian conflict ceded, Europe, wary of any form of conflict on its territory that could shatter its peace and economic building block project- the European Union - opted for the role of a peacemaker and imposed sanctions. Economic sanctions are seen as the better option rather than direct military conflict with Russia.

One of the many questions that the Russian-Ukrainian conflict raised for Europe's security was the status of nuclear armed states, and in particular, the relevance of tactical nuclear weapons that are hosted on European NATO member states' territories. While NATO is a strategic alliance, for which, nuclear deterrent is a primary goal, ${ }^{12}$ strategic nuclear deployment better serves that goal as opposed to tactical nuclear weapons.

\footnotetext{
9 Stockholm International Peace Research Institute, SIPRI Yearbook 2014: Armaments, Disarmament and International Security. 45 ${ }^{\text {th }}$ ed. Oxford, UK: Oxford University Press, 2014. 12.

${ }^{10}$ Glenn Diesen, "EU and NATO Relations with Russia After the Collapse of the Soviet Union." PhD diss. University of Amsterdam, 2015, 266-267.

11 Sam Perlo-Freeman et al, "Trends in World Military Expenditure, 2015," SIPRI Fact Sheet, April 2016, 2, http://books.sipri.org/files/FS/SIPRIFS1604.pdf (noting that Russia's military expenditure in 2015 was $66.4 \mathrm{~b}$ USD when compared to a decade earlier when spending was 3.5b USD in 2005).

12 "NATO Strategic Concept for the Defence and Security of the Members of the North Atlantic Treaty Organization," adopted by Heads of State and Government at the NATO Summit in Lisbon, 19-20 November 2010, http://www.nato.int/nato_static_fl2014/assets/pdf/pdf_publications/20120214_strategic-concept-2010-eng.pdf.
} 


\section{THE INTERMEDIATE RANGE NUCLEAR FORCES TREATY}

In this section of the article, I will demonstrate that the Intermediate-Range Nuclear Forces Treaty (INF) has been largely successful, or rather, it achieved its core mission of banning weapons capable of delivering nuclear warheads over certain distances. Thus, to replicate that success, the INF should form a core part of the NPT.

During the waning years of the Cold War, Moscow and Washington signed the $\mathrm{INF}^{13}$ in 1987 to eliminate intermediate-range and short-range missiles with a range of up to 5,500 kilometers. In practice this meant that both the US and Russia pledged to ban all ballistic and cruise missiles with that specific range and all the technology associated with those missiles that were capable of delivering a nuclear warhead.

The INF Treaty required the complete elimination of just over 800 US and more than 1,800 former Soviet ground-launched missiles with a range of up to 5,500 kilometers. All missiles were eliminated by May 28, 1991. ${ }^{14}$ The INF Treaty required onsite inspections of the dismantling process ${ }^{15}$ and prohibited parties from producing or testing any new intermediate or short-range missiles or launchers capable of delivering a nuclear warhead. ${ }^{16}$

The INF Treaty has been perhaps the most solid foundation of the nuclear arms control treaties because of its success in actual disarmament and early compliance by both Moscow and Washington. When the INF was signed by Ronald Reagan and Mikhail Gorbachev in 1987, a revolution of a different kind was going on in the Soviet Union, as perestroika and glasnost charmed Soviet citizens. During that same year, Reagan urged Gorbachev to "tear down" the Berlin Wall. But more importantly, the arms race was taking its financial toll on the Soviet Union and to a lesser extent the United States. The maintenance of nuclear arms was costlier than before and in 1987 Moscow and Washington possessed a combined total of 61,682 nuclear warheads. ${ }^{17}$

\footnotetext{
${ }^{13}$ The Treaty Between the United States of America and the Union of Soviet Socialist Republics on the Elimination of their Intermediate-Range and Shorter-Range Missiles, U.S.-U.S.S.R., Dec. 8. 1987, 1657 U.N.T.S. 2. The INF Treaty is accompanied by a comprehensive Memorandum of Understanding (MOU) on Data, the Protocol on Inspections, and the Protocol on Elimination. These documents were later followed up with three sets of diplomatic notes and an agreed minute on May 12,1988. The latter confirming that the INF Treaty applied to the technology for weapons during the time the treaty was signed and on future technology.

${ }^{14}$ U.S. State Department, "Adherence to and Compliance with Arms Control, Non-proliferation, and Disarmament Agreements and Commitments," (July 12, 2014): 8.

15“"Intermediate-Range Nuclear Forces Treaty (INF Treaty)," Article X(2).

${ }^{16}$ Ibid., Article VI(1).

${ }^{17}$ Robert Norris \& Hans Kristensen, "Global Nuclear Weapons Inventories, 1945 - 2013," Bulletin of the Atomic Scientists 69 (2013): 3, http://dx.doi.org/10.1177/0096340213501363.
} 
The INF Treaty set specific ceilings for disarmament, and at the time the treaty was signed, those ceilings pertained to intermediate-range and short-range missiles, specifically Pershing II and BGM-109G, SS-20, SS-4, SS-5; Pershing IA, SS-12 and SS-23 cruise and ballistic missiles. ${ }^{18}$ For example, the ceilings in the INF Treaty included 925 deployed and non-deployed intermediate range missiles by the US and 1,476 by the Soviets. ${ }^{19}$ The number typology is set out in the accompanying memorandum of understanding (MOU) to the INF Treaty, and when those numbers are compared to other nuclear arms control treaties, the INF stands in a league of its own because of the amount of nuclear warheads it categorically called for eliminating in specific numbers.

There was genuine concern in Europe about the Soviet and US blanket of the continent with nuclear warheads. The nuclear arms race that began in the 1950s saw various Soviet missiles deployed on Warsaw Pact member territory and threatened the security of NATO members in Western Europe. ${ }^{20}$ However, because Washington used its strategic nuclear arsenal to pledge the security of NATO members in Europe, it was only during the negotiations for the INF Treaty that Washington actually placed intermediate and short range nuclear weapons in Europe.

Those weapons - cruise and ballistic missiles with a range of 5,500 kilometers-along with their delivery vehicles, were placed in the Netherlands, Belgium, Italy, Germany, and the UK in 1983. Washington also placed other tactical nuclear weapons in these NATO Member States. Although it was a 1979 NATO decision to deploy American missiles on NATO members' territories, the US also wanted 'to limit the Soviets' growing, modern, highly accurate, roadmobile, MIRVed (multiple independently targetable reentry vehicles), medium-range ballistic missile force," and in light of this, negotiations for the INF Treaty began in $1981 .^{21}$

After the entry into force of the INF Treaty on June 8, 1988, it was envisaged that within three years all land-based cruise and ballistic missiles and their related deployment mechanisms in Europe that the Soviets and the Americans deployed would be eliminated. ${ }^{22}$ The three-year time frame set by the INF Treaty for reductions ended in June 1991, and, by then, the Soviets destroyed 1,846 weapons compared to the 846 destroyed by the United States. ${ }^{23}$

Today the INF Treaty is still in force, because of its "unlimited duration," and requires a six-month notification period in case one party decides to withdraw due to matters that

\footnotetext{
${ }^{18}$ The Treaty Between the United States of America and the Union of Soviet Socialist Republics on the Elimination of their Intermediate-Range and Shorter-Range Missiles, Article III, U.S.-U.S.S.R., Dec. 8. 1987, 1657 U.N.T.S. 2.

${ }^{19}$ U.S. Department of State, "Intermediate-Range Nuclear Forces Treaty: Memorandum of Understanding Regarding the Establishment of the Data Base for the INF Treaty, Section II(1)," (Washington, DC, 1987).

${ }^{20}$ Cahit Aycan, "The Impact of the Intermediate-Range Nuclear Forces Treaty on Turkey's Defense Requirements" (Research Report, Alabama Air War College, 1989), 4.

${ }_{21}$ Thomas Graham and Damien Lavera, "The Intermediate-Range Nuclear Forces Treaty," in Cornerstones of Security: Arms Control Treaties in the Nuclear Era, (Seattle: University of Washington Press, 2002), 512.

${ }^{22}$ The Treaty Between the United States of America and the Union of Soviet Socialist Republics on the Elimination of their Intermediate-Range and Shorter-Range Missiles, Articles IV(1) and IV(2)(b), U.S.-U.S.S.R., Dec. 8. 1987, 1657 U.N.T.S. 2.

${ }^{23}$ Avis Bohlen et al., "The Treaty on Intermediate-Range Nuclear Forces: History and Lessons Learned," Brookings Arms Control Series 9 (2012): 13.
} 
"jeopardized its supreme interests" as a result of "extraordinary events" pertaining to the INF Treaty. ${ }^{24}$

Although the INF is one of the lingering remnants of the Cold War nuclear arms control treaty system, it has so far been the most effective treaty in international nuclear arms control because it involves the two major nuclear superpowers and because the INF Treaty set specific ceilings for disarmament, which has largely been successful in eliminating entire classes of nuclear weapons.

But most of the technology that was related to the ground-launchers, cruise, and ballistic missiles under the INF Treaty has become obsolete and new technologies have put the INF Treaty into serious doubt.

There are a number of suspicions by the parties to the INF Treaty, especially Russia and the United States, that either side have breached the terms of the INF Treaty by testing new weapon systems with a range of more than 5,500 kilometers, the maximum the INF provides for, thus violating the terms of the INF Treaty. ${ }^{25}$ For its part the US has blamed Russia for violating the INF Treaty while on the other hand, Russia has suggested that the US has also violated the INF Treaty with the development of new technology including drones capable of delivering nuclear warheads.

These suspicions prevailed regardless of the compliance mechanism under Article XIII of the INF Treaty - the Special Verification Commission (SVC) - to address all concerns relating with their obligations and compliance with the INF Treaty. ${ }^{26}$ Such suspicions are best seen as part of a de-compliance regime in international law. Whether or not the terms of the INF Treaty are being violated, there is the need to multilateralize the INF Treaty so that it is capable of addressing new technologies and bringing on board the other nuclear armed states and the rest of the international community that is concerned about disarmament.

\footnotetext{
${ }^{24}$ The Treaty Between the United States of America and the Union of Soviet Socialist Republics on the Elimination of their Intermediate-Range and Shorter-Range Missiles, Articles XV(1) and (2), U.S.-U.S.S.R., Dec. 8. 1987, 1657 U.N.T.S. 2.

${ }^{25}$ U.S. Department of State, "Intermediate-Range Nuclear Forces Treaty: Memorandum of Understanding Regarding the Establishment of the Data Base for the INF Treaty, Section II(1)," (Washington, DC, 1987): 8. The State Department notes that Russia violated the INF: "The United States has determined that the Russian Federation is in violation of its obligations under the INF Treaty not to possess, produce, or flight-test a ground-launched cruise missile (GLCM) with a range capability of $500 \mathrm{~km}$ to $5,500 \mathrm{~km}$, or to possesses or produce launchers of such missiles."

${ }^{26}$ The Treaty Between the United States of America and the Union of Soviet Socialist Republics on the Elimination of their Intermediate-Range and Shorter-Range Missiles, Article XIII(1), U.S.-U.S.S.R., Dec. 8. 1987, 1657 U.N.T.S. 2.
} 
The seeds for multilateralism of the INF Treaty were already sown in 1991 after the collapse of the Soviet Union and successor states such as the Ukraine, Belarus, Turkmenistan, Uzbekistan, and Kazakhstan joined Russia and assumed responsibility for Soviet obligations under the INF Treaty. Some of those states had been subjected to inspection due to INF Treaty compounds that they inherited despite the elimination of the missiles the INF Treaty required in the months before the collapse of the Soviet Union. ${ }^{27}$ Of the Soviet successor states, four participated in the SVC and still hold that position today-Belarus, the Ukraine, Kazakhstan, and Russia - and the SVC could be the main vehicle for multilateralism to expand the INF Treaty to nuclear armed states that possess short- and medium-range nuclear weapons. But, prior to November 2016, the last meeting of the SVC was in $2003,{ }^{28}$ and during that time the relevance of the INF Treaty has been questioned due to the lack of SVC activities.

Russia itself has been a champion of multilateralism for the INF Treaty and analysts suggests that even if the INF Treaty could be multilateralized, ten other states would need to be persuaded to join the INF Treaty. ${ }^{29}$ Since 1991, the number of nuclear armed states has grown; furthermore, the traditional nuclear armed states also acquired more advanced weapons technology, when compared to the same weapons that were banned under the INF. The US and Russia have also used advances in technology to circumvent the INF Treaty to develop and test similar or more advanced forms of nuclear capable vehicles that the INF Treaty bans.

Furthermore, because the true goal of the INF Treaty was to reduce the spread of Soviet intermediate-range nuclear missiles in Europe, that goal was already accomplished by 1991, when those weapons were decommissioned along with those that the US had in Europe. During the negotiations of the INF Treaty that began in 1981, the US was able to skillfully place a number of its intermediate range nuclear weapons in Western Europe to use as a bargaining chip with the Soviets. All those factors, along with the sitting of the SVC in 2003 and 2016, serve only to remind us that the INF Treaty was for a particular period of time and for certain types of nuclear capable vehicles. $^{30}$

But times and circumstances have changed over the decade since the sitting of the SVC in 2003 and a follow up sitting in November 2016, and the technology that was relevant to the INF Treaty has now become obsolete and the number of states that are in possession of nuclear weapons such as France, the UK, India, Pakistan, and Israel are, in a sense, in possession of intermediate-

\footnotetext{
${ }^{27}$ Bohlen et al., "The Treaty on Intermediate-Range Nuclear Forces," 21.

${ }^{28}$ U.S. Department of State, "Adherence to and Compliance with Arms Control," 19.

${ }^{29}$ Bohlen, et al., "The Treaty on Intermediate-Range Nuclear Forces, 22-23. The author asserts that "at least ten states other than the United States and Russia" would need to come on board the INF, and suggests that China, Egypt, India, Iran, Israel, North Korea, Pakistan, Saudi Arabia and Syria possessed weapons the INF bans.

${ }^{30}$ Since this article was written, the SVC met in November 2016. U.S. Department of State, "Thirtieth Session of the Special Verification Commission Under the Treaty Between the United States of America and the Union of Soviet Socialist Republics on the Elimination of their Intermediate Range and Shorter Range Missiles (INF Treaty)," (Geneva, Switzerland, Nov. 15-16, 2016): https://2009-2017.state.gov/r/pa/prs/ps/2016/11/264375.htm.
} 
range nuclear weapons. These weapons can be considered more of a regional deterrent if they reach up to 5,500 kilometers. These countries will argue that their nuclear arsenal is "strategic" and, as such, necessary for their security. It is also for this very reason that the multilateralizing of the INF Treaty to cover these nuclear armed states is also necessary. The benefits of bringing these states into a multilateral treaty banning short- and intermediate-range nuclear weapons can be twofold: firstly, the number of nuclear arms states would be reduced drastically and thus limit proliferation; and secondly, the road to near zero disarmament would be much smoother. This latter goal however, is not necessarily practical.

However, a multilateral INF Treaty alone cannot produce the goal of nonproliferation and disarmament. A multilateral INF Treaty can bring stability, certainty, and greater compliance to international nuclear arms control. In the wake of regional conflicts, such as those in the spring of 2014 with the re-annexation of the Crimea by Russia or any re-escalation of conflict on the Indian sub-continent, an INF Treaty that is global in scope would bring certainty that no nuclear weapons would be used in the theatre of combat. Such uncertainties cannot be guaranteed under the current status quo of limiting the INF Treaty only to Russia, the Soviet successor states and the United States. Furthermore, Western European countries that currently host tactical nuclear weapons on behalf of the United States should also engage in a dialogue process of globalizing the INF Treaty as it would bring more security to them in the fear of Russia using nuclear weapons capable of reaching their capitals that are not banned under the INF Treaty.

Europe has been at peace for over six decades in 2016, and apart from skirmishes on Europe's eastern borders involving Russian and Ukrainian forces over the self-determination of Russian-speaking citizens in the Ukraine and the territorial status of the Crimea, peace in Europe still appears to be on solid foundation. NATO has largely been responsible for the continued peace in Europe, due to the fact that most European states are members of NATO - a strategic alliance for nuclear deterrence. ${ }^{31}$ But most EU countries are in the direct firing line of newer technologies that are capable of delivering nuclear weapons to their doorsteps from Russia, and technically, such weapons do not fall within the ambit of the INF Treaty. At the same time Moscow and other major Russian cities are also in the firing line from weapons based in Western Europe that are banned under the INF. However, a new INF Treaty could result in such countries being removed from the direct firing line of Moscow and, where Washington were to remove its tactical nuclear weapons in Europe, could lead to better engagement with Moscow on disarmament and nonproliferation.

\footnotetext{
${ }^{31}$ North Atlantic Treaty Organization, “Lisbon Summit Declaration,” (Lisbon, Portugal, November 19-20, 2010 ): 5.
} 


\section{AMENDING THE NUCLEAR NON-PROLIFERATION TREATY TO BAN TACTICAL NUCLEAR WEAPONS}

To build upon the success of the INF Treaty, the NPT Treaty should be amended to incorporate the INF Treaty given that the NPT Treaty is a multilateral treaty agreed to by most nations in the world. There is no need for a new independent treaty as negotiation can take years. However, the NPT is attractive because it has been given indefinite extension, and this allows it to be more appealing than a new treaty or expansion of the INF, which is limited to tactical weapons.

During the height of the Cold War, a number of tactical nuclear weapons were deployed in Western European States such as Germany, Belgium, Italy, and the Netherlands in order to respond to any perceived aggression from the Soviet Union. ${ }^{32}$ However, despite these measures, the deadly effects of nuclear weapons were never ignored and earlier steps to eliminate nuclear weapons culminated with the entry into force in 1970 of the Nuclear Non-Proliferation Treaty (NPT). ${ }^{33}$ A number of countries, including the former Soviet Union and the United States, signed up to the NPT Treaty pledging to stop the spread of nuclear weapons and avoid nuclear wars. The NPT Treaty allows for its members to gather every five years to review its operation. The next NPT review conference takes place in 2020 and, ideally, one of the outcomes of that NPT review conference would be an amendment to the NPT Treaty requiring states to ban tactical nuclear weapons in Europe ${ }^{34}$ and other parts of the world. A revised NPT treaty would effectively prevent other states from acquiring nuclear weapons or could lead to a zero endgame or a world free of nuclear weapons. ${ }^{35}$

The current global arsenal of nuclear weapons is just over 17,000 with Russia and the United States accounting for more than 90 percent of that amount. ${ }^{36}$ The remainder is shared among Pakistan, India, Israel, and the NATO members, France and the UK. In this context, the continent of Europe is fully nuclear armed from the Isles of Britannia (to include America's tactical nuclear weapons stationed in Belgium, Germany, Italy, Turkey, and the Netherlands) to the docks of Vladivostok (taking into account Russia's nuclear arsenal). Of the total global nuclear arsenal, it is estimated that between Russia and the United States there are some 7,000 tactical nuclear weapons either deployed or ready to be deployed in short combat zones and conflict areas.

\footnotetext{
${ }^{32}$ Dakota Rudesill, "Regulating Tactical Nuclear Weapons,” The Georgetown Law Journal 102, no. 1 (2013): $99-175$.

${ }^{33}$ Treaty on the Non-Proliferation of Nuclear Weapons, 729 UNTS 161, (July 1, 1968).

34 Hans Kristensen and Adam Mount, "Why NATO Should Eliminate its Tactical Nukes, Despite Russian Belligerence," Bulletin of the Atomic Scientists, September 3, 2014; Peter Doran and Kingston Reif. "Opening Address." Debate on tactical nuclear weapons held by the Center for Strategic and International Studies' Project on Nuclear Issues, Washington, DC, March 19, 2014. The authors argue that tactical nuclear weapons are not useful in reassuring the security of Eastern European NATO states. While I endorse these views in this discussion, what separates my arguments is a proposal to amend the NPT to achieve such goals.; David Koplow, "What Would Zero Look Like? A Treaty for the Abolition of Nuclear Weapons," Georgetown Journal of International Law 45, no. 3 (2014): 734.

35 David A. Koplow, "What Would Zero Look Like?" 734.

${ }^{36}$ Joseph Cirincione, Nuclear Nightmares: Securing the World Before it is Too Late (New York: Columbia University Press, 2013), 9, 40; Stockholm International Peace Research Institute, SIPRI Yearbook 2014, 12.
} 
A deployment of a tactical nuclear weapon is capable of eliminating a city or certain percentage of a population, as compared to the deployment of strategic nuclear weapons that are programmed for Armageddon or mutually-assured-destruction. However, the deployment of a tactical nuclear weapon in short conflict zones can also have impact beyond its intention and could also trigger Armageddon if either Russia or the United States were to respond with their strategic nuclear weapons, if they felt they were also under attack. For NATO, the alliance's strategic nuclear forces are primarily those of the United States which forms the backbone as "the supreme guarantee of the security of the Allies,"37 and this has added pressure on the US to respond in particular times of aggression to the needs of NATO. In this regard, NATO sees the need for the so called "appropriate mix" of different capabilities including strategic and tactical nuclear weapons to respond to its needs. This was also confirmed in NATO's Posture Review in $2012 .^{38}$

Given how effective the INF Treaty has been in nuclear disarmament, ${ }^{39}$ especially in its early years when more than 2,600 missiles were eliminated after the INF Treaty came into force, ${ }^{40}$ it has the potential to replicate that success at the global level via multilateralism. But in recent years, the INF has been in a state of de-compliance-an intricate process of compliance and deception of compliance-where the parties uphold the tenets of the document, but at the same time carry out testing on modern nuclear weapons vehicles such as nuclear capable ground cruise missiles.

When the United States and Russia pledged to prevent conflicts or casualties in case of an attack by eliminating tactical nuclear weapons vehicles such as ground-to-air cruise missiles under the INF Treaty, some measure of disarmament was reached. Both Russia and the United States committed themselves to eliminate nuclear and conventional ground-launched ballistic and cruise missiles with a range of up to 5,500 kilometers. ${ }^{41}$

\footnotetext{
${ }^{37}$ North Atlantic Treaty Organization, "Strategic Concept for the Defense and Security of the Members of the North Atlantic Treaty Organisation," point 18.

${ }^{38}$ North Atlantic Treaty Organization, "Deterrence and Defence Posture Review," May 20, 2012: para 32. The release claims, "NATO is committed to maintaining an appropriate mix of nuclear, conventional, and missile defence capabilities for deterrence and defence to fulfil its commitments."

39 Arms Control Association, The Intermediate-Range Nuclear Forces (INF) Treaty at a Glance, (May 14, 2014). This details success of disarmament in Eastern Europe.

${ }^{40}$ United States Department of State Bureau of Arms Control, Verification, and Compliance, "Treaty Between the United States of America and The Union of Soviet Socialist Republics On The Elimination Of Their IntermediateRange and Shorter-Range Missiles (INF Treaty)," narrative (December 8, 1987).

${ }^{41}$ The Treaty Between the United States of America and the Union of Soviet Socialist Republics on the Elimination of their Intermediate-Range and Shorter-Range Missiles, Articles 7(4) and 12(3), U.S.-U.S.S.R., Dec. 8. 1987, 1657 U.N.T.S. 2.
} 
While most weapons designated in the INF Treaty were eliminated, there has been continued fear that each party, in their quest to modernize their nuclear arsenal, broke the terms of the INF Treaty. This occurred in spite of the compliance mechanism that the INF treaty establishes under Article XIII - the Special Verification Commission (SVC) ${ }^{42}$ — to resolve questions relating to compliance ${ }^{43}$ and to take measures to "improve the viability and effectiveness" of the INF Treaty. ${ }^{44}$ The INF Treaty itself has been a peculiar treaty in that it is the only strategic treaty that actually leads to disarmament, and that is significant when compared to previous treaties such as SALT I I $^{45}$ and II $^{46}$ that lead to the START treaties ${ }^{47}$, and also the 2010 START (Treaty on Measures for the Further Reduction and Limitation of Strategic Offensive Arms), which foresees a reduction of nuclear weapons. ${ }^{48}$

The success of the INF Treaty in banning nuclear short-and intermediate-range cruise missiles could serve as a tool to give some impetus to the NPT Treaty, in particular banning tactical nuclear weapons. Both the NPT Treaty and the INF Treaty serve essentially the same goal of disarmament, and the INF Treaty should be incorporated into the NPT Treaty to ban tactical nuclear weapons, as the INF Treaty has now become somewhat outdated as new technologies eclipse its terms. One way of incorporating the INF Treaty into the NPT Treaty is to amend Article VI of the NPT Treaty. I will return to this point shortly, but first, some context within broader international law.

The problem of nuclear weapons in international law has always been a contentious issue and even the International Court of Justice (ICJ) is so aware of the problems relating to nuclear weapons that it saw fit to stay neutral on such matters. For instance, when the ICJ was faced with the question of whether nuclear weapons should be a prerogative of the World Health Organization $(\mathrm{WHO})^{49}$, the ICJ in an advisory opinion reinforced the disarmament provision of the NPT Treaty and proclaimed that states have an obligation to pursue nuclear disarmament treaties.

\footnotetext{
${ }^{42}$ Ibid., Article 13(1).

${ }^{43}$ Ibid., Article 13(1)(a).

${ }^{44}$ Ibid., Article 13(1)(b).

${ }^{45}$ Interim Agreement on Certain Measures with Respect to the Limitation of Strategic Offensive Arms (SALT I Interim Agreement), U.S.-U.S.S.R., May 26, 1972, 23 U.S.T. 3462; Strategic Arms Limitation Joint Resolution (SALT I Resolution in the United States), U.S. - U.S.S.R., 1972, 92-448, 86 Stat. 746. These two instruments made up the SALT I Agreement.

46 Treaty on the Limitation of Strategic Offensive Arms (SALT II), U.S. - U.S.S.R., June 18, 1979, 25 T.S. 96.

47 Treaty on the Reduction and Limitation of Strategic Offensive Arms (Start I), U.S. - U.S.S.R., July 31, 1992,20 T.S. 102); U.S. Department of State, Treaty on Further Reduction and Limitation of Strategic Offensive Arms (Start II), S. Treaty Doc. No. 103-01 (January 3, 1993).

${ }^{48}$ Treaty Between the United States of America and the Russian Federation on Measures for the Further Reduction and Limitation of Strategic Offensive Arms, U.S. - R.U., April 8, 2010, 50 ILM 345; Lisa Schenck and Robert Youmans, "From Start to Finish: A Historical Review of Nuclear Arms Control Treaties and Starting Over with the New Start," Cardozo Journal of International and Comparative Law 20 (2012): 399.

${ }^{49}$ Legality of the Threat or Use of Nuclear Weapons, Advisory Opinion, 1996 I.C.J. 105(2)(F), 227-228 (July 8).
} 
Whether or not it was the prerogative of the WHO, the ICJ stayed clear of that and instead argued that the conclusion of disarmament treaties should be done in good faith. In the $W H O$ Legality Opinion, the ICJ was called upon to interpret Article VI of the NPT which called upon states to negotiate in good faith nuclear disarmament treaties, and the Court explained that "there exists an obligation to pursue in good faith and bring to a conclusion negotiations to nuclear disarmament in all its aspect under strict and effective international control." ${ }^{50}$ At the heart of the WHO Legality Opinion was the NPT Treaty that entered into force in 1970 and how it has been essential to world peace.

The NPT Treaty was given a new lease on life in 1995 when it was extended to remain in force indefinitely and thus making it the crème-del-a-crème avenue for disarmament. ${ }^{51}$ The NPT Treaty has also been responsible for a sort of MAD-détente in world peace and security in that signatory members agreed to halt the proliferation of nuclear weapons and nuclear weapons technology. The Strategic Concept of NATO also envisages a world free of nuclear weapons ${ }^{52}$ and the NPT Treaty has been at work to accomplish that goal.

The NPT Treaty was born out of fear of the destructive nature of nuclear weapons (strategic and tactical) and, in a way similar to that of the INF Treaty, brought home some amount of disarmament. The NPT Treaty also sought disarmament, because disarmament, non-proliferation, and the right to peacefully use nuclear technology are the backbone of the NPT Treaty or the so called "pillar" structures.

According to Article I of the NPT Treaty, member states committed themselves "not to transfer to any recipient whatsoever nuclear weapons or other nuclear explosive devices or control over such weapons or explosives" and to also take measures from preventing non-nuclear states from acquiring nuclear weapons. ${ }^{53}$ And equally, under Article II of the NPT Treaty, non-nuclear states pledged not to acquire nuclear weapons or nuclear weapons technology. While under Article III, the task of safeguards and verification has been entrusted to the International Atomic and Energy Agency (IAEA) to ensure that members are in compliance with the NPT Treaty or that nuclear technology is used for peaceful purposes. ${ }^{54}$ Thus, in Articles I-III of the NPT Treaty, the

\footnotetext{
${ }^{50}$ Ibid.

51 The 1995 Review and Extension Conference of the Parties to the Treaty on the Non-Proliferation of Nuclear Weapons, "Organization and Work of the Conference," Annex, U.N. Doc. NPT/CONF.1995/32 (May 11, 1995): Part 1.

${ }^{52}$ North Atlantic Treaty Organization, "Strategic Concept For the Defence and Security of the Members of the North Atlantic Treaty Organisation," point 26.

${ }^{53}$ Treaty on the Non-Proliferation of Nuclear Weapons, Article I, Mar. 5, 1970, 729 U.N.T.S. 161.

${ }^{54}$ Ibid., Article III.
} 
pillars of peaceful use of nuclear technology and non-proliferation of nuclear weapons and technology are embedded whilst the third pillar — disarmament — can be found in Article VI of the NPT Treaty. ${ }^{55}$

In terms of disarmament, the NPT provides in Article VI that there is an obligation on members to pursue disarmament. The exact provision states, "[e]ach of the Parties to the Treaty undertakes to pursue negotiations in good faith on effective measures relating to cessation of the nuclear arms race at an early date and to nuclear disarmament, and on a treaty on general and complete disarmament under strict and effective international control." ${ }^{56}$ When the terms of this provision are closely analyzed one interpretation is that there is a need for a global disarmament treaty without the piecemeal approach such as in the START treaties or the INF Treaty ${ }^{57}$ However, a new global disarmament treaty is problematic from many angles, including the number of years to negotiate, and that is why my emphasis is on revising the NPT as the main avenue for global disarmament to include the INF.

As this paper has pointed out, given the success of the INF Treaty, it could transform into a global disarmament treaty if it were to be incorporated into the NPT Treaty. This could be done by amending Article VI of the NPT Treaty. Though the INF Treaty is limited to certain transport vehicles for nuclear warheads, such limitations contributed in its early success on disarmament.

However, the INF Treaty could be expanded into a multilateral treaty so that the remaining nuclear-armed states sign up to it. One way of expanding the INF Treaty into a multilateral treaty is to amend Article VI of the NPT Treaty, so that it is incorporated fully under the NPT Treaty to include all nuclear-armed states, and an obligation to disarm all tactical nuclear weapons. By doing so, a global disarmament treaty (i.e., revised NPT) could be negotiated in good faith, and thus comply with Article VI - the disarmament provision of the NPT Treaty. The revision clause of the NPT requires the Parties to convene a conference 25 years after its entry into force "to decide whether the [NPT] shall continue in force indefinitely, or shall be extended for an additional fixed period or periods.. ${ }^{58}$ The parties used this opportunity in 1995 to allow the NPT to continue in force indefinitely, and this clause could also be used to reflect incorporating the INF Treaty into the NPT Treaty.

The most effective way of amending the NPT Treaty to ban tactical nuclear weapons in Europe and globally would be for Europe to lead initiatives and convince the non-nuclear weapons member states that banning of such weapons will make the world somewhat safer. If non-nuclear weapons states are fully engaged in the disarmament process they would be able to extend leverage

\footnotetext{
${ }^{55}$ Paul Kiernan, "Disarmament Under the NPT: Article VI in the 21st Century," Michigan State University College of Law International Law Review 20, no. 2 (2012): 381; David Jonas, "General and Complete Disarmament: Not Just for Nuclear Weapons States Anymore," Georgetown of International Law 43, no. 3 (2012): 587.

${ }^{56}$ Treaty on the Non-Proliferation of Nuclear Weapons, Article VI, Mar. 5, 1970, 729 U.N.T.S. 161.

${ }^{57}$ David A. Koplow, "What Would Zero Look Like?"

${ }^{58}$ Treaty on the Non-Proliferation of Nuclear Weapons, Article X(2), Mar. 5, 1970, 729 U.N.T.S. 161.
} 
over other nuclear armed states to seek their commitments that, in the event of further conflicts, they will refrain from introducing tactical nuclear weapons in the theatre of combat. ${ }^{59}$

On a broader level where the strategic and tactical nuclear weapons of both Russia and the United States are concerned, their commitment under an amended NPT Treaty to limit their nuclear arsenal to less than 200 each per country would be the ultimate goal of disarmament where a zero endgame would prove impossible. Two hundred might be seen as an unrealistic figure, but it would be a massive reduction from current figures and inching towards zero. Furthermore, a revised NPT Treaty incorporating the INF Treaty should address nuclear warheads as opposed to the vehicles and technology capable of delivering those warheads, because the INF Treaty has fallen into a state of quiescence since the 2003 sitting of the SVC. Nor did the 2016 sitting of the SVC produce any results apart from commitments to work together in the future. In light of this, an amended NPT Treaty may yet deliver the international nuclear arms control process from the shadows of the adversarial relations of the Cold War.

An amendment to the NPT banning tactical nuclear weapons would ensure that the amount of nuclear weapons globally is reduced and contribute to global ambitions, such as those in the 2010 START and other venues. Moreover, an amendment to Article VI of the NPT to ban tactical nuclear weapons can result in a more vigorous form of disarmament - the "zero-sum" game. ${ }^{60}$ The impetus is then to amend Article VI of the NPT Treaty and incorporate the INF Treaty and negotiate nuclear disarmament in good faith, because as things stand, Article VI of the NPT Treaty is the only legally-binding treaty that commits states to nuclear disarmament.

Although it is often easier to pull out of an arms control agreement, such as the US withdrawal from the ABM Treaty and Russia's withdrawal from the CFE Treaty, than amending an arms control agreement, other hurdles are not insurmountable. Thus, while potential hurdles, such as domestic political opposition, could delay amendment, unforeseen developments could also accelerate the need for amendment. Other potential obstacles to amendments, such as the setting up of verification mechanisms to monitor agreed reduction of nuclear arms, or questions of trust and security concerns, could be overcome by strengthening the SVC. ${ }^{61}$

\footnotetext{
${ }^{59}$ Thomas Graham, "International Law and the Proliferation of Nuclear Weapons," George Washington International Law Review 33, no. 1 (2001): 49, 68. This paper discusses similar views in relation to all nuclear weapons.; Haralambos Athanasopulos, Nuclear Disarmament in International Law (Jefferson, NC: McFarland and Company, 2000).

${ }^{60}$ David A. Koplow, "What Would Zero Look Like?"

${ }^{61}$ Burrus M. Carnahan \& Katherine L. Starr, "Law and Policy in the Amendment of Arms Control Agreements," Loyola International and Comparative Law Journal 20 (1998): 615, 616. Note 4 cites the ABM as an example of an
} 


\section{CONCLUSION}

Although the possibility of nuclear war or mutually assured destruction is not at the same level as it used to be during the Cold War, other conflicts such as in the Middle East, the Indian Subcontinent, and parts of Europe such as in Ukraine, where tactical weapons are present, and could be deployed in the theatre of conflict, present a danger to world peace and security. One way of erasing such a threat is to completely ban all forms of tactical weapons capable of carrying nuclear warheads. The first step in that direction is to amend the NPT and incorporate the INF thereby producing a revised NPT as a major global disarmament treaty.

\section{POSTSCRIPT}

In March 2017, the United Nations General Assembly convened a conference to negotiate a legally binding instrument to prohibit nuclear weapons, leading towards their total elimination. Although most of the major nuclear weapons states boycotted the conference, what was historic was the fact that such a multilateral conference took place at the UN, reinforcing the notion that zero disarmament might be possible. The conference was in part based on a UNGA Resolution for disarmament negotiations. ${ }^{62}$

arms control agreement that underwent "modifications and attempted reinterpretations," and at page 618 the authors give a historical reference to treaty amendments.

${ }^{62}$ UN General Assembly, Draft Resolution/A/C.1/71/L.41, "Taking Forward Multilateral Nuclear Disarmament Negotiations," October 14, 2016, para 8, http://www.un.org/ga/search/view_doc.asp?symbol=A/C.1/71/L.41. 